\title{
Effects of external gamma radiation on femoral artery reimplantation in rats. Morphometrical analyzes ${ }^{1}$
}

\author{
Regina de Faria Bittencourt da Costa ${ }^{2}$ \\ Djalma José Fagundes ${ }^{3}$ \\ Yara Juliano ${ }^{4}$ \\ Neil Ferreira Novo ${ }^{4}$ \\ Wilma Therezinha Trench Vieira ${ }^{5}$
}

\begin{abstract}
Costa RFB, Fagundes DJ, Juliano Y, Novo NF, Vieira WTT. Effects of external gamma radiation on femoral artery reimplantation in rats: morphometrical analyzes. Acta Cir Bras [serial online] 2003 Mar-Apr;18(2). Available from URL: http://www.scielo.br/acb.

ABSTRACT - Purpose: To investigate the effects of external gamma radiation on rat femoral artery reimplant. Methods: Sixty-two male Wistar rats were distributed in two groups I (Control) and II (Irradiated), both formed by three observation subgroups: 2 (10 animals), 7 (11) and 21(10) postoperative days (PO). The right femoral artery of each animal was split up and reimplanted (end-to-end anastomosis), through microsurgery technique. In the first PO day group II animals were irradiated with a single dose of $15 \mathrm{~Gy}$, external source. The histological analysis, qualitative and descriptive analysis, was accomplished through hematoxylin and eosin (HE), Verhoeff and Masson trichromium methodology. Morphometric analysis was realized in the same slides used to histological analysis stained by HE. Computer software was used to quantify morphological alterations of the vascular wall, by processing captured images from a microscope. It was analyzed the intimal layer (intimal hyperplasia and endothelium cells formation) and the nuclei percentage of smooth muscular cell in the medium layer and in the intima hyperplasia. The data were treated applying the statistical tests: Fisher's exact, Chi-square, Mann-Whitney, Kruskal-Wallis and analysis of variance $(\mathrm{p}<.05)$. Results: The patency graft was observed by microscope distal to the autograft in $93.5 \%$ (29/31). It was observed that the gamma-radiation reduced the degree of covering of the vascular wall for the neo-formed endothelium. The nuclei percentage of smooth muscular cells, in the media, was smaller compared to control animals, although it was no significant for the studied sample size. The irradiated group showed a significant lower luminal stenosis and the intimal hyperplasia occurrence. In this group the percentage of smooth muscular cells proliferation, in the media, were significantly lower for 7 and 21 days of observation. Conclusion: The external single dose of $15 \mathrm{~Gy}$ gamma-radiation delivered at first postoperative day may inhibit the endothelial cells regeneration and the percentage of lumen stenosis and prevents intimal hyperplasia, in the 2 , 7 and 21 PO on femoral artery autograft in rats.
\end{abstract}

KEY WORDS - Ionizin radiation. Radiation effects. Reimplant. Femoral artery. Rats.

\section{Introduction}

Intimal hyperplasia is a result of the vessel wall's response to injury and characterized by proliferation and migration of medial smooth muscle cells (SMC)

with associated deposition of extracellular connective tissue matrix ${ }^{1,2}$.

1. Tese de Doutorado apresentada no Programa de Pós-Graduação em Técnica Operatória e Cirurgia Experimental da Universidade Federal de São Paulo - Escola Paulista de Medicina (UNIFESP-EPM). Trabalho laureado com os Prêmios: Prêmio Saul Goldenberg no IV Fórum de Pesquisa em Cirurgia Experimental/I Jornada Paulista de Pesquisa em Cirurgia Experimental e Prêmio Emil Burhian ( $3^{\circ}$ lugar) no VII Panamerican Congress on Vascular and Endovascular Surgery.

2. Doutora em Medicina pelo Programa de Pós-Graduação em Técnica Operatória e Cirurgia Experimental da UNIFESP-EPM.

3. Coordenador do Programa de Pós-Graduação em Técnica Operatória e Cirurgia Experimental da UNIFESP-EPM.

4. Professores Adjuntos da Disciplina de Bioestatística, do Departamento de Medicina, UNIFESP-EPM.

5. Médica do Departamento de Patologia do Hospital Heliópolis - São Paulo. 
To a certain extent, intimal hyperplasia is present in all types of vascular reconstructions including autologous and prosthetic grafts ${ }^{3}$, found in solid organ allografts, having a substantial role in chronic reaction ${ }^{4,5}$ and it is responsible for restenosis following angioplasty, particularly with stenting ${ }^{(6)}$.

This process causes intimal thickening leading to luminal stenosis or restenosis and complicates a significant part of endovascular and open vascular procedures, which often translates into clinical ischemia ${ }^{7,8}$

Therefore, the control of intimal hyperplasia would have important clinical applications. Several strategies have been tested and studied in an attempt to control intimal hyperplasia including pharmacological agents, new mechanical devices and gene therapy ${ }^{9,10,11}$. However, the modest success achieved in animal models could not be reproduced in clinical trials.

The search for newer prevention modalities has focused on the area of ionizing radiation, a potent antiproliferative agent, which has been utilized for decades by oncologists to control cellular proliferation in both malignancy and benign proliferative conditions $\mathrm{s}^{9,11,12}$.

Gamma radiation affects self-renewing tissues by causing cell death during cell division and limiting proliferation. Since proliferative cells are radiosensitive, radiation therapy may be useful ${ }^{13,14,15}$.

Vascular SMCs are normally not actively dividing cell populations. However, vessel injury can induces a hyperplasic response of SMCs within the vessel wall characterized by SMC proliferation and migration; it follows that radiation should effectively inhibit intimal formation in rapidly dividing $\mathrm{SMCs}^{16,17}$.

To define the in vivo effect of external gammaradiation on anastomotic arterial autogenous graft wall with emphasis on neo-formed endothelium, actively proliferating SMCs in medial layer and in $\mathrm{IH}$, and its implications on stenosis, we used rat femoral artery autograft to stimulate $\mathrm{IH}$ and delivered a single dose (15Gy) gamma radiation to injured vessels at first postoperative day.

The aim of this study was evaluation of the effects of gamma radiation on femoral artery reimplant in rats.

\section{Methods}

This experimental study was approved by the São Paulo Hospital Institutional Ethical Research Committee of Universidade Federal de São Paulo - Escola Paulista de Medicina (UNIFESP-EPM) (protocol 928/99) and the "Guide for Care and Use of Laboratory Animals" (18) (of the United States Society for Medical Research) was followed.
Male Wistar rats (Charles River Laboratories, Wilmington, Delaware.), weighing 450 to $550 \mathrm{~g}$, threeto four- months old, were obtained from Centro de Desenvolvimento de Modelos Experimentais para Medicina e Biologia (CEDEME / UNIFESP-EPM) was used in experimental study.

It was administered xylazine $(10 \mathrm{mg} / \mathrm{Kg}$ subcutaneous) and anesthetized with intraperitoneal chloral hydrate $(15 \mathrm{mg} / \mathrm{Kg})$ and thiopental sodium $(30 \mathrm{mg} / \mathrm{Kg})$. So they were laid on a heating pad, controlled to $37^{\circ} \mathrm{C}$.

The right femoral artery of each animal, $3 \mathrm{~mm}$ long segment, was split up. The lumen was flushed with heparinised saline and the segment stored in heparinised saline for 10 minutes. So it was performed the reimplant under microscopic magnification by means of eight to ten evenly spaced 10-0 monofilament nylon suture at each anastomosis.

Then it was waited 10 minutes and patency graft observed by microscope mainly distal to the graft. Only the patent grafts were considered for study.

In the first PO both animals group received xylazine $(10 \mathrm{mg} / \mathrm{Kg}$ subcutaneous) and thiopental sodium $(30 \mathrm{mg} / \mathrm{Kg}$ intraperitoneal). They were distributed in two groups: I (Control) and II (Irradiated), formed by three subgroups: 2 (10 animals), 7 (11) and 21 (10) postoperative days (PO).

Group II animals were placed in a thermical custom $\left(37^{\circ} \mathrm{C}\right)$ and the right femoral artery was exposed to a single dose of $15 \mathrm{~Gy}$ gamma radiation. This radiation was calculated in the wounded area of the skin, using ${ }^{60}$ Co source (CGR, Alcyon II) delivering 64,09 cGy/ min, being positioned on an acrylic shield $5 \times 5 \mathrm{~cm}$ field with $0,5 \mathrm{~cm}$ thickness, at $80 \mathrm{~cm}$ from emitter source in the Radiotherapy Section from Medical Department UNIFESP-EPM.

The rats were anaesthetized as initial operation at 2, 7 and $21 \mathrm{PO}$ and tissue samples containing the graft and about $2 \mathrm{~mm}$ of the adjacent femoral artery were harvest and stained with hematoxylin and eosin, Verhoeff and tricromic Masson.

The euthanasia was realized in anesthetized rats by an overdose of $19.9 \% \mathrm{KCl}$, in the right femoral vein.

Histological analysis: After being blocked in paraffin vascular tissue was cut in transversal sections (4 mm thick). All sections were examined with a light microscopy. The anastomotic region with the best image was chosen to analyze it.

Descriptive and qualitative analysis was realized in the anastomotic area graft in all vascular wall. The following specific features were observed for: 
1. Endothelial cells regeneration. The internal elastic lamina (IEL) was first identified, and the presence was determined by the presence of nuclei of endothelial cells above the IEL. Presence of one nucleus in one high-power field (X40 objective), however, may be due to artifacts. Therefore, the presence of at least two nuclei in one high-power field (X40) was taken as the criterion for endothelial cell regeneration ${ }^{19}$.

2. Intimal hyperplasia (IH). If the cellularity of smooth muscle cells above the internal elastic lamina was increased to more than two cells layers in thickness, the specimen was classified as positive for IH. A thickness of two cell layers or less is not significant, as oblique cuts of a normal intima may give this picture ${ }^{19}$.

3. Reaction of foreign-type to the nylon thread in the adventitial tunica. Presence of Langhans' or foregein-type giant cells.

4. Medial necrosis. Evidence of loss of nuclei, thinning, or fibrinoid degeneration.

Morphometric analysis: A morphometric analysis was preferencial on the same sections utilized for qualitative and descriptive analyses.

Color video images of grafts sections $(280 \times 360$ $\mathrm{mm}$ fields) were captured (Video Capture Tool. Microsoft Video Cap., Windows 98) using a 10x or 40x objective (Carl Zeiss/Axiostar microscope) and digitalized by a video camera (Sony Hyper HAD), via an Intel, $350 \mathrm{MHz} / 64 \mathrm{Mb}$ RAM (Pentium II) computer running a software to quantify morphological alterations (Imagelab 2000).

The region of interest of each captured image was indicated by the operator and its area was automatically analyzed by the software after standardization with a microscale slide in $\mathrm{mm}$.

For the comparison of intimal hyperplasia development video images were captured with $10 \mathrm{x}$ objective, and stenosis percentage of the luminal area were calculated and described as the stenosis percentage: anastomotic graft cross-sectional area of the vascular luminal (L) / vascular luminal + intimal hyperplasia areas $\mathrm{x} 100$.

In order to evaluate the percentage of smooth muscle cell present in intimal hyperplasia and in media layer the digital images (40x objective) were captured to computer software that quantified the nuclei of these cells (indirect measurement). The color images were splitted into their red, blue and green components. The percentage presence of SMC nuclei was observed at green histogram.

Each selected image was measured five times and the average was determinate.

Statistical analysis: The data were treated applying the statistical tests: Fisher's exact or Chi-square to compare groups. Kruskal-Wallis analysis of variance by ranks to compare the weight variation, \% smooth muscle cell percentage. Mann-Withney test to compare two independents groups, smooth muscle cell nuclei in the media layer and in intimal hyperplasia. The level of significance was set at $\mathrm{p}<.05$ or $5 \%$.

\section{Results}

Rats tolerated the surgery and the $15 \mathrm{~Gy}$ irradiation without apparent effect, except mild depilitation at the irradiation site at $21 \mathrm{PO}$. The patency rate graft, evaluated by microscope mainly distal to the autograft, was observed in 29/31 grafts (93.55\%) in both groups. There was no mortality in both groups. None of the groups had thrombosis dependent on the time of examination after operation.

\section{Histological analysis}

Histological analysis demonstrated endothelial cell regeneration significant in control group. All samples at 7 and $21 \mathrm{PO}$ had endothelial cells in vascular lumen. All grafts of experimental group were denuded of endothelial cells at 2 days after grafting, which was significant compared with 7 and 21 PO subgroups (Table 1, Figure 1).

TABLE 1 - Porcentage of animals with present endothelial cells in the grafted femoral artery anastomosis.

\begin{tabular}{cccccc}
\hline Subgroup & \multicolumn{2}{c}{$\begin{array}{c}\text { Control Group } \\
(\mathrm{n}=31)\end{array}$} & $\begin{array}{c}\text { Irradiated Group } \\
(\mathrm{n}=31)\end{array}$ & Among PO days \\
\hline Postoperative (PO) day & $\mathrm{n}_{\mathrm{s}}\left(\mathrm{n}_{\mathrm{t}}\right)$ & $\mathrm{n}_{\mathrm{s}} \%$ & $\mathrm{n}_{\mathrm{s}}\left(\mathrm{n}_{\mathrm{t}}\right)$ & $\mathrm{n}_{\mathrm{s}} \%$ & P value $^{(1)}$ \\
2 & $3(10)$ & 30 & $0(10)$ & 0 & $0.10(\mathrm{NS})$ \\
7 & $10(11)$ & 90 & $4(11)$ & 36 & $0.01(*)$ \\
21 & $10(10)$ & 100 & $7(10)$ & 70 & $0.11(\mathrm{NS})$ \\
\hline
\end{tabular}

Within each group, P value ${ }^{(2)} 0.0005\left(^{*}\right) \quad 0.005(*)$

${ }^{(1)} \mathrm{P}$ value determined with Fisher exact test among groups of the same PO day or ${ }^{(2)} \mathrm{c}^{2}$ within each group; $\left(_{*}\right)$ statiscally significant differences $(\mathrm{P}<.05)$; NS, no statiscally significant; $\mathrm{n}$, total number of animals in each group; $n_{s}$, number of animals analyzed with present endothelial cells in each PO; $\left(n_{t}\right)$, total number of animals analyzed in each PO 
A

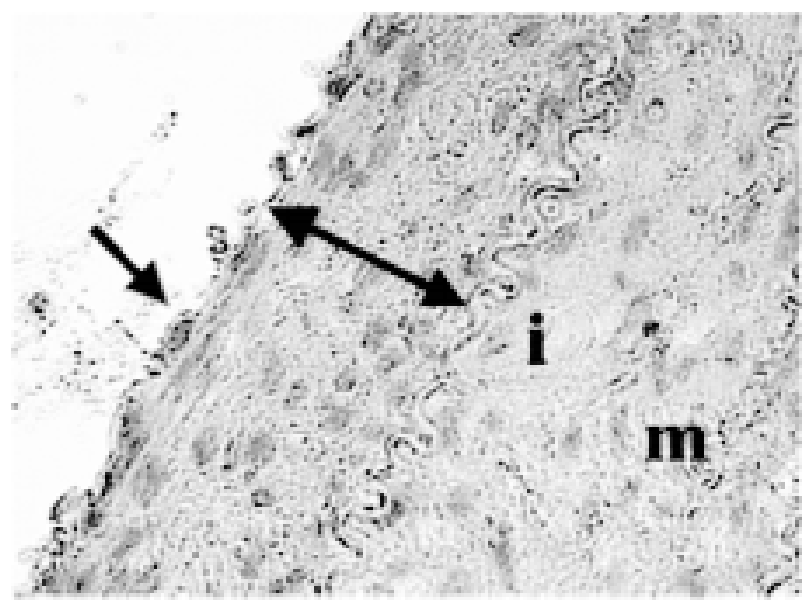

C

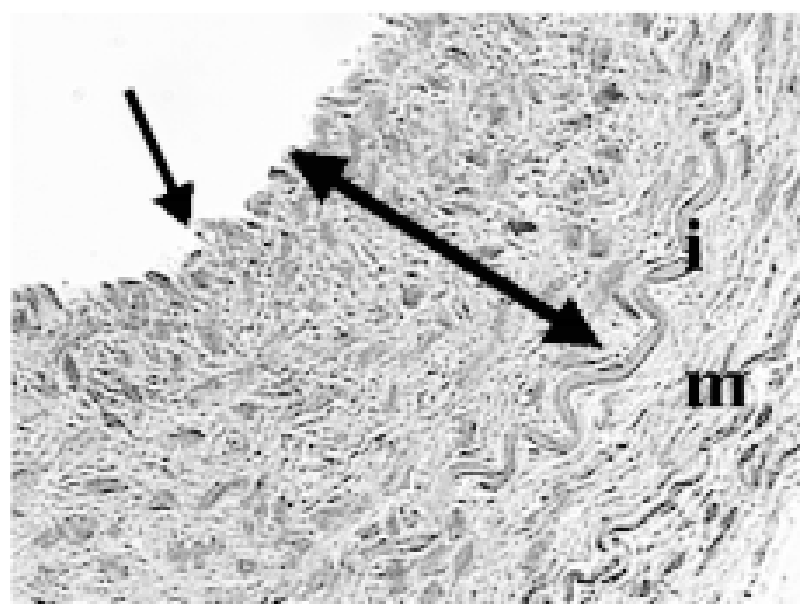

B

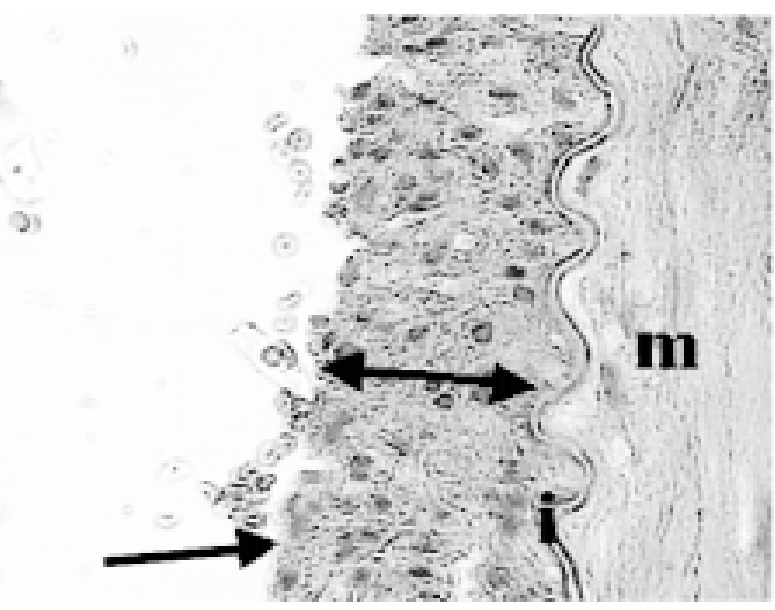

D

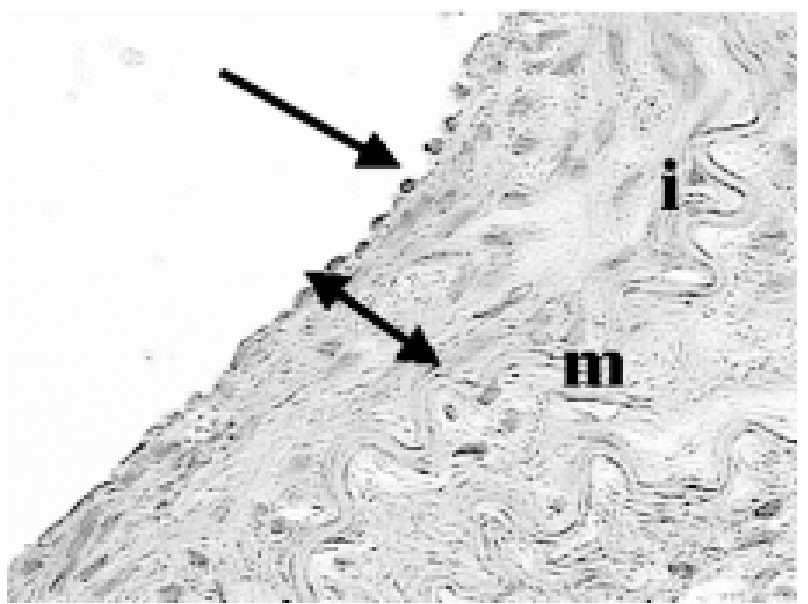

FIGURE 1 - A and C show cross-sections of two grafted femoral arteries of control animals, B, D the same for two irradiated animals; Double arrows ( $\ll$ ) show intimal hyperplasia, $\mathrm{IH}$, between vascular lumen and internal elastic layer (I, tortuous sctructure) in graft femoral artery sections at $21 \mathrm{PO}$; Arrows (A, B, C and D) located inside arterial lumen appear for neoformed endothelial cells on HI; $\mathrm{A}, \mathrm{B}, \mathrm{C}$ and $\mathrm{D}$ show medial layer identified by the letter $\mathrm{m}$. All present nuclei of SMCs were stanned in blue (hematoxylin and eosin). Magnification: 40X magnification.

The thickness of the intimal hyperplasia was not uniform and varied greatly within and between grafts of the same age. Control group showed a significant improved in intimal hyperplasia $21 \mathrm{PO}$ compared with 2 and 7 PO (Table 2, Figure 2). Intimal hyperplasia formation was revealed in all specimens at $21 \mathrm{PO}$ suggesting that this disease experimental model was suitable to develop intimal hyperplasia in the PO observation and might be used as control group to evaluate the effects of radiation.

TABLE 2 - Porcentage of animals with present intimal hyperplasia (IH) in the graft anastomosis.

\begin{tabular}{cccccc}
\hline Subgroup & \multicolumn{2}{c}{$\begin{array}{c}\text { Control Group } \\
(\mathrm{n}=31)\end{array}$} & $\begin{array}{c}\text { Irradiated Group } \\
(\mathrm{n}=31)\end{array}$ & Among PO days \\
\hline Postoperative (PO) day & $\mathrm{n}_{\mathrm{s}}\left(\mathrm{n}_{\mathrm{t}}\right)$ & $\mathrm{n}_{\mathrm{s}} \%$ & $\mathrm{n}_{\mathrm{s}}\left(\mathrm{n}_{\mathrm{t}}\right)$ & $\mathrm{n}_{\mathrm{s}} \%$ & $\mathrm{P}_{\text {value }}{ }^{(1)}$ \\
2 & $0(10)$ & 0 & $0(10)$ & 0 & $\mathrm{~N} / \mathrm{A}$ \\
7 & $6(11)$ & 55 & $0(11)$ & 0 & $0.0006(*)$ \\
21 & $10(10)$ & 100 & $3(10)$ & 30 & $0.0016(*)$ \\
\hline Within each group, P value ${ }^{(2)}$ & \multicolumn{3}{c}{$0.0004(*)$} & N/A \\
\hline
\end{tabular}

(1) P value determined with Fisher exact test among groups of the same PO day or ${ }^{(2)} \mathrm{c}^{2}$ within each group; ${\left({ }_{*}\right)}_{*}$, statiscally signficant differences $(\mathrm{P}<.05)$; N/A, not applicable; $n$, total number of animals in each group; $\mathrm{n}_{\mathrm{s}}$, number of animals analyzed with present IH in each PO and $n_{t}$, number of animals analyzed in each PO. 


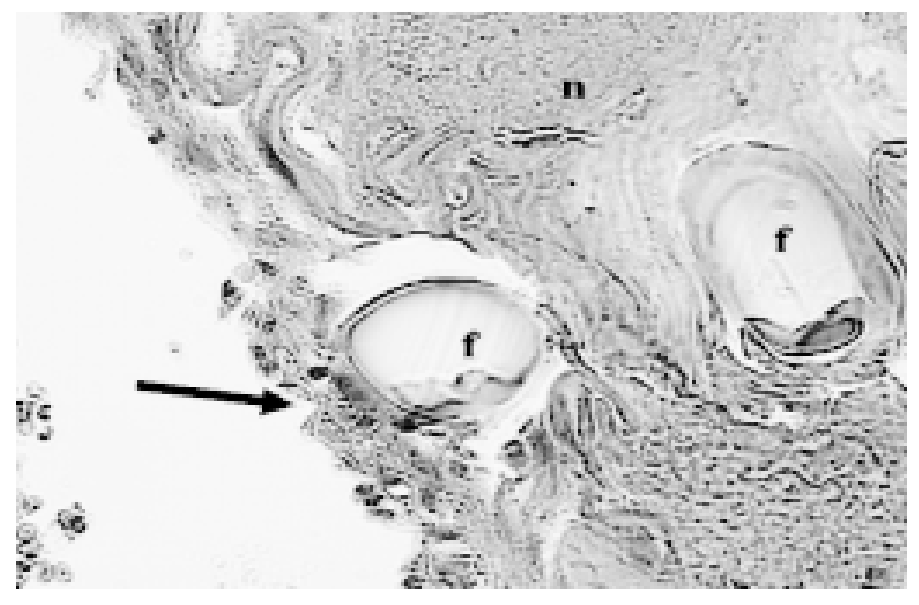

FIGURE 2 - Located focal necrosis in the areas adjacent to the thread (f) and among the loops of the same. It is noticed that the surgical thread was covered for the intimal hiperplasia shown with the arrow. (hematoxylin and eosin : 40X magnification).

Stenosis percentage at 7 and 21 PO showed a significant reduction in stenosis at irradiated group compared with control. At 21 PO irradiated group the stenosis was significantly reduced compared with control group (Table 3, Figure 3).

TABLE 3 - Stenosis percentage in the grafted femoral artery sections with intimal hyperplasia (IH).

\begin{tabular}{cccccc}
\hline Subgroup & \multicolumn{2}{c}{$\begin{array}{c}\text { Control group } \\
(\mathrm{n}=31)\end{array}$} & \multicolumn{2}{c}{$\begin{array}{c}\text { Irradiated group } \\
(\mathrm{n}=31)\end{array}$} & Among PO days \\
\hline Postoperative (PO) day & $\mathrm{n}_{\mathrm{s}}$ & Stenosis $\%$ & $\mathrm{n}_{\mathrm{s}}$ & Stenosis $\%$ & Uvalue $^{(1)}$ \\
2 & 0 & 0 & 0 & 0 & N/A \\
7 & 6 & $27,8 \mathrm{z}$ & 0 & 0 & N/A \\
21 & 10 & $59,7 \mathrm{z}$ & 3 & 24,6 & $3^{*}$ \\
\hline
\end{tabular}

${ }^{(1)} \mathrm{U}$ value determined with Mann-Whitney test among groups of the same PO day; $\left({ }^{*}\right)$ statiscally significant differences among $21 \mathrm{PO}$ days $\left(\mathrm{U}>\mathrm{U}_{\mathrm{c}}=0\right.$ fixed for $\left.\mathrm{P}=.05\right)$; N/A, not applicable; $\mathrm{zU}$ value between 7 and $21 \mathrm{PO}$ days within of the control group was no statiscally significant $\left(\mathrm{U}=15<\mathrm{U}_{\mathrm{c}}=11\right.$ fixed for $\left.\mathrm{P}=.05\right)$; $\mathrm{n}$, total number of animals in each group; $n_{s}$, number of animals analyzed with present IH in each PO and $n_{t}$, number of animals analyzed in each PO. 
A

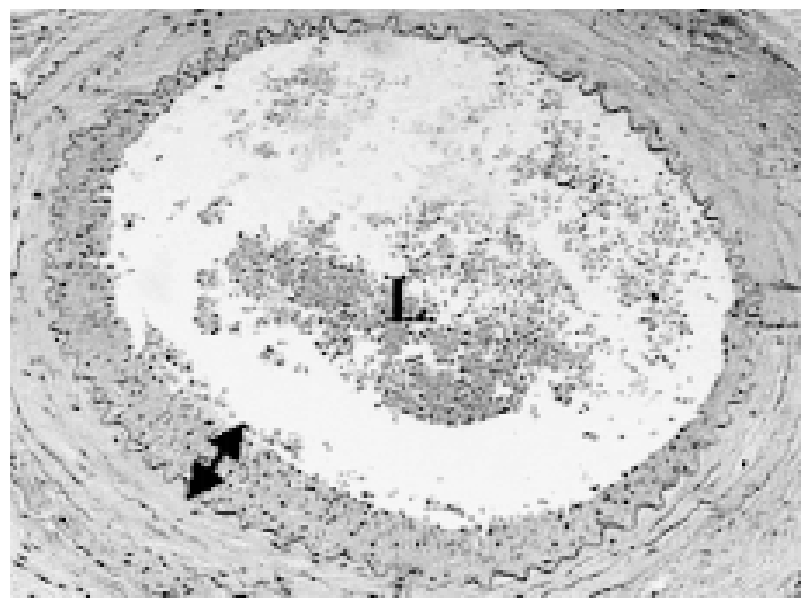

C

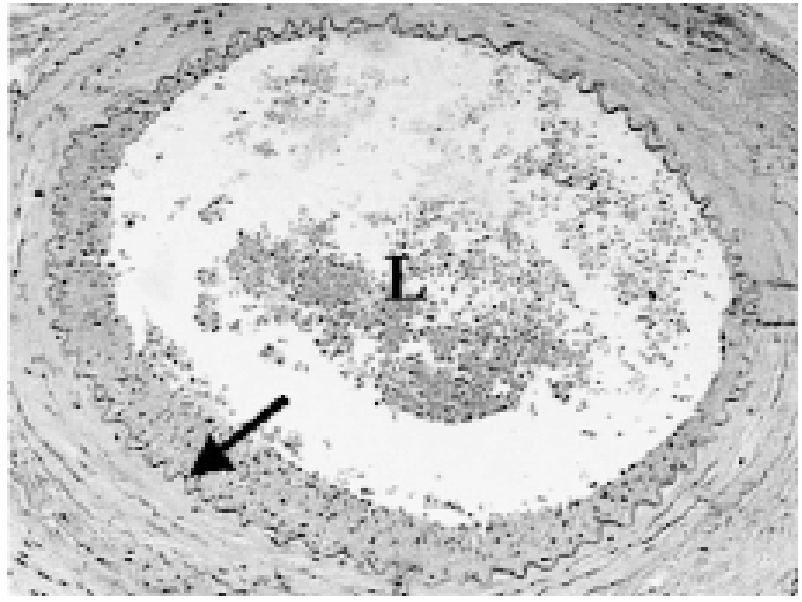

B

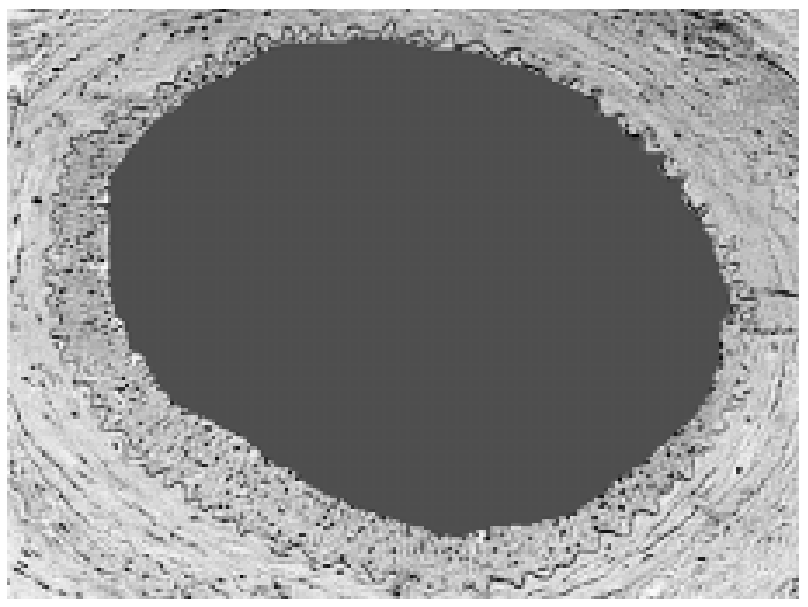

D

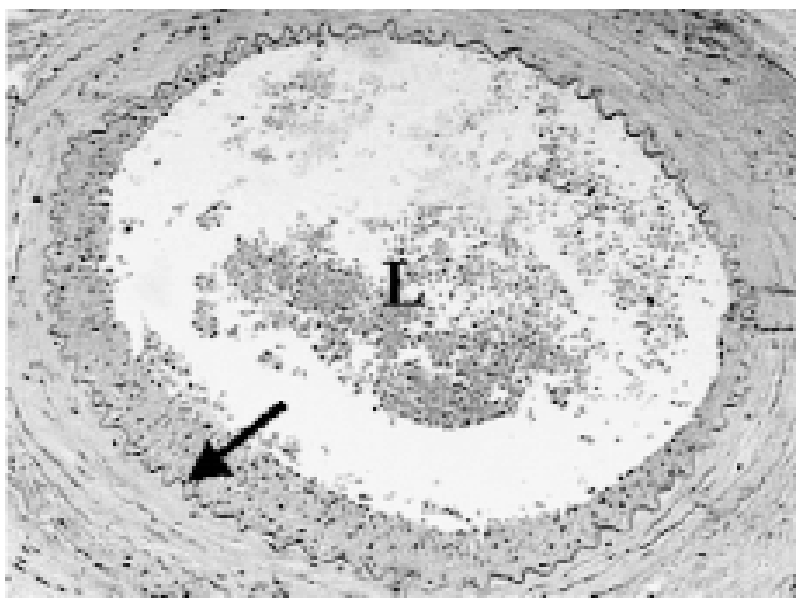

FIGURE 3 - It identifies the arterial structures, besides illustrating the sequence adopted with aid of a computer program to determine the stenosis degree of an graft femoral artery section (Irradiated group at $21 \mathrm{PO}$ ). A, display the vascular lumen (L) and the intimal hyperplasia (double arrows, $\leftrightarrow$ ), B, detaches the internal elastic layer with a large arrow. The area selection of the vascular lumen (blue), it is shown in B, whereas D includes the vascular lumen plus the intimal hyperplasia (blue area).

The presence of SMC nuclei percentage in intimal hyperplasia was higher in control group compared with irradiated one. However, between controls subgroups at $7 \mathrm{PO}$ the presence of SMC nuclei were significantly higher than $21 \mathrm{PO}$ (Table 4, Figure 4).

TABLE 4 - Nuclei percentage of smooth muscle cells (SMCs) in specimen sections analyzed with intimal hyperplasia (IH).

\begin{tabular}{cccccc}
\hline Subgroup & \multicolumn{2}{c}{$\begin{array}{c}\text { Control group } \\
(\mathrm{n}=31)\end{array}$} & \multicolumn{2}{c}{$\begin{array}{c}\text { Irradiated group } \\
(\mathrm{n}=31)\end{array}$} & Among PO days \\
\hline Postoperative (PO) day & $\mathrm{n}_{\mathrm{s}}$ & Stenosis $\%$ & $\mathrm{n}_{\mathrm{s}}$ & Nuclei $\%$ & U value $^{(1)}$ \\
2 & 0 & 0 & 0 & 0 & N/A \\
7 & 6 & 27,8 & 0 & 0 & N/A \\
21 & 10 & 19,2 & 3 & 15,3 & 12 (NS) \\
\hline
\end{tabular}

${ }^{(1)} \mathrm{U}$ value determined with Mann-Whitney test among groups of the same PO day; N/A, not applicable; NS, no statiscally significant differences; U value calculated between 7 and $21 \mathrm{PO}$ days within of the control group was statiscally significant $\left(\mathrm{U}=5.5<\mathrm{U}_{\mathrm{c}}=11\right.$ fixed for $\left.\mathrm{P}=.05\right)$; $\mathrm{n}$, total number of animals in each group; $\mathrm{n}_{\mathrm{s}}$, number of animals analyzed with nuclei \% of SMCs in each PO with present $\mathrm{HI}$ and $\mathrm{n}_{\mathrm{t}}$, number of animals analyzed in each PO. 
A

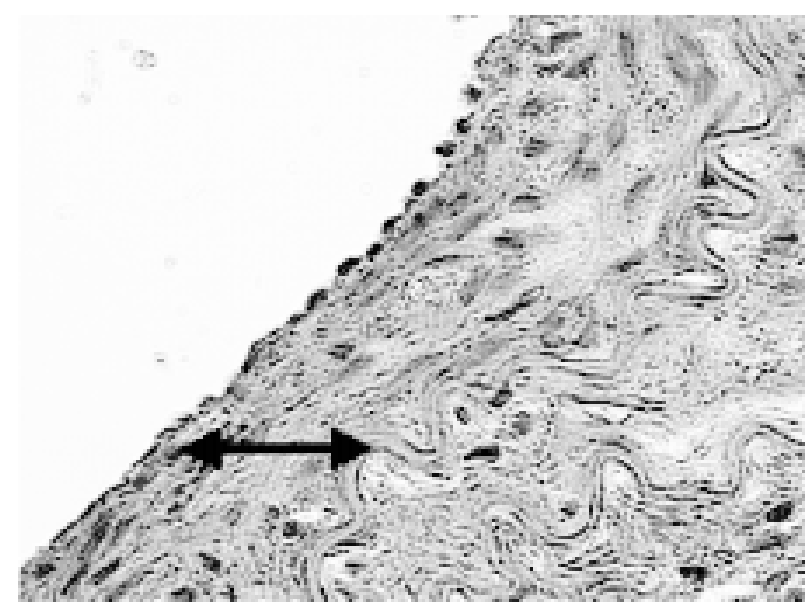

C

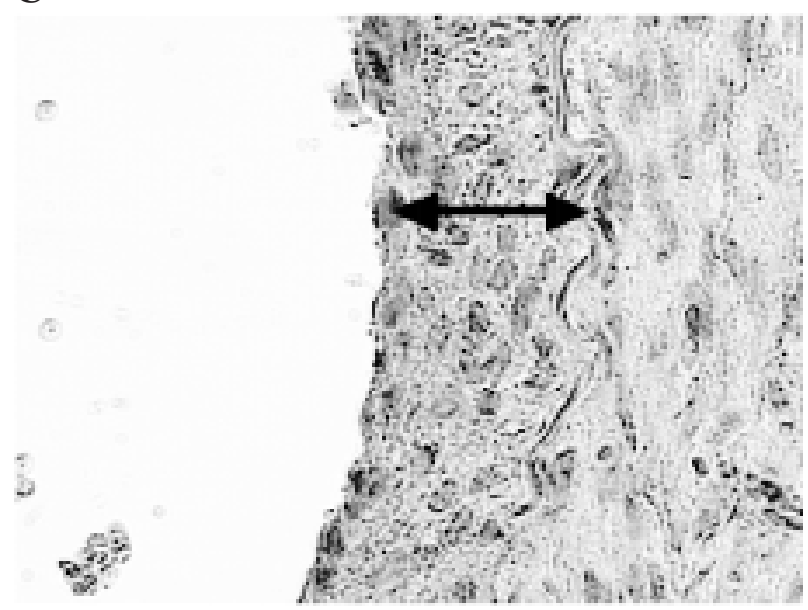

$\mathbf{B}$

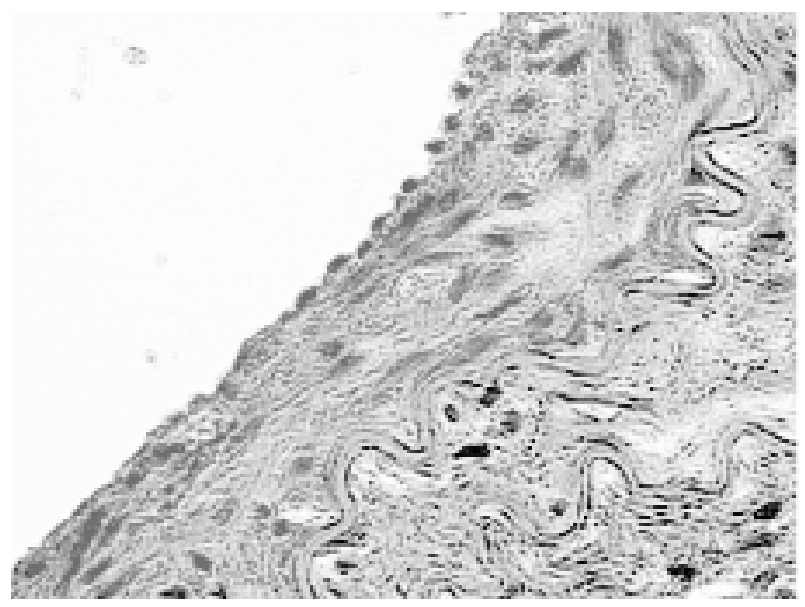

D

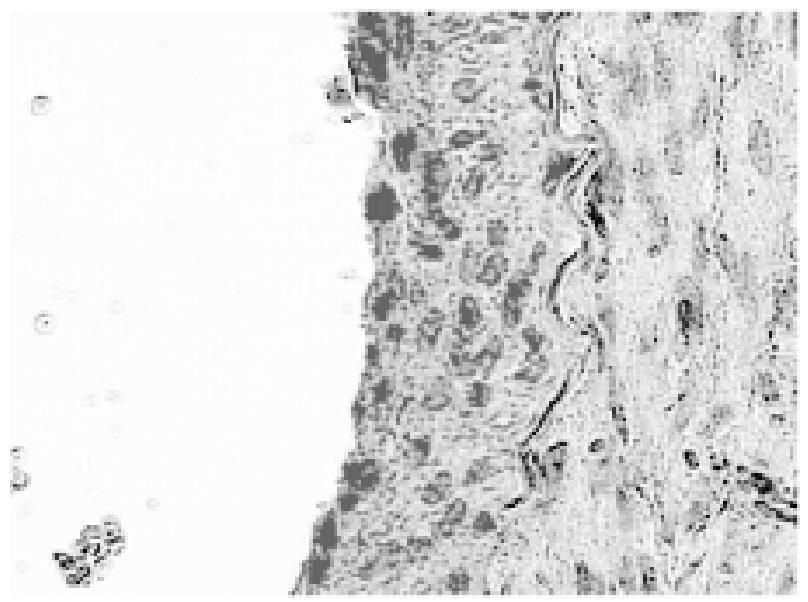

FIGURE 4 - Photomicrographs showing the computer analyze of the presence of nuclei of smooth muscle cells i in intimal hyperplasia («), stained in blue. Irradiated group in A (21 days) and B image analyzed by the computer system; control group in C (21 days) and $\mathrm{D}$ image analyzed. (hematoxylin and eosin $-10 \mathrm{X}$ magnification).

The percentage of SMC in medial layer was significantly higher at control group compared with experimental one (Table 5, Figure 5).

TABLE 5 - Nuclei mean percentages of smooth muscle cells (SMCs) in the medial layer.

\begin{tabular}{|c|c|c|c|c|c|}
\hline Subgroup & \multicolumn{2}{|c|}{$\begin{array}{l}\text { Control group } \\
(\mathrm{n}=31)\end{array}$} & \multicolumn{2}{|c|}{$\begin{array}{l}\text { Irradiated group } \\
(\mathrm{n}=31)\end{array}$} & Among PO days \\
\hline Postoperative (PO) day & $\mathrm{n}_{\mathrm{s}}$ & Nuclei \% & $\mathrm{n}_{\mathrm{s}}$ & Nuclei \% & Uvalue $^{(1)}$ \\
\hline 2 & 10 & 5,90 & 10 & 5,1 & 44(NS) \\
\hline 7 & 11 & 12,9 & 11 & 6,4 & $3.5(*)$ \\
\hline 21 & 10 & 16,6 & 10 & 6,1 & $0.0(*)$ \\
\hline H vakye ${ }^{(2)}$ & \multicolumn{2}{|c|}{$20.2^{*}$} & \multicolumn{2}{|c|}{$1.5(\mathrm{NS})$} & $\mathrm{U}_{\mathrm{c}}$ value $^{(3)}$ \\
\hline $\mathrm{H}_{\mathrm{c}}$ value $^{(3)}$ & & & & & 23 \\
\hline
\end{tabular}

${ }^{1} \mathrm{U}$ value determined with Mann-Whitney test among groups of the same $\mathrm{PO}$ day; ${ }^{2} \mathrm{H}$ value determined with Kruskall-Wallis test within each group; ${ }^{3}$ Fixed for $\mathrm{P}=.05$; NS, no statiscally significant; $\left({ }^{*}\right)$ statiscally significant differences $\left(\mathrm{U}<\mathrm{U}_{\mathrm{c}}\right.$ or $\left.\mathrm{H}>\mathrm{H}_{\mathrm{c}}\right) ; \mathrm{n}$, total number of animals in each group; $\mathrm{n}_{\mathrm{s}}$, number of animals analyzed with nuclei $\%$ of SMCs in given PO and $n_{t}$, number of animals analyzed in each PO. 
A

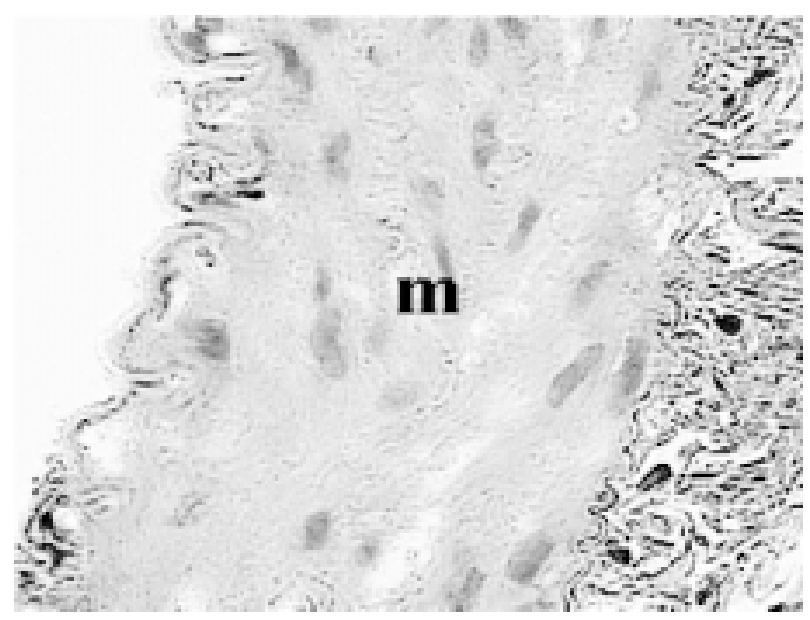

C

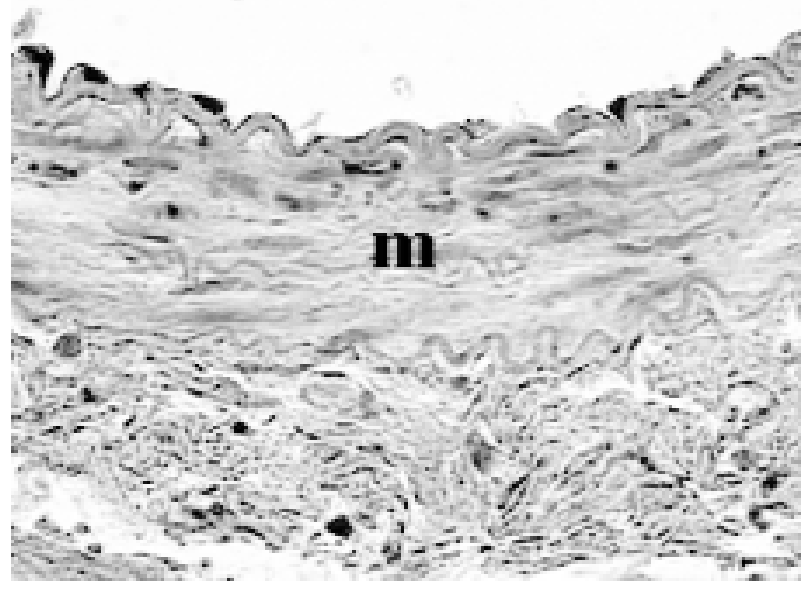

B

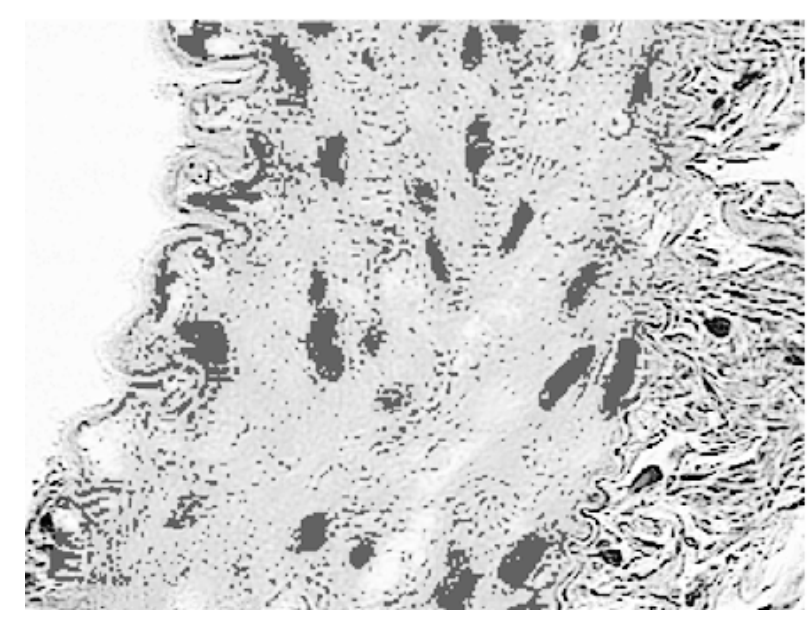

D

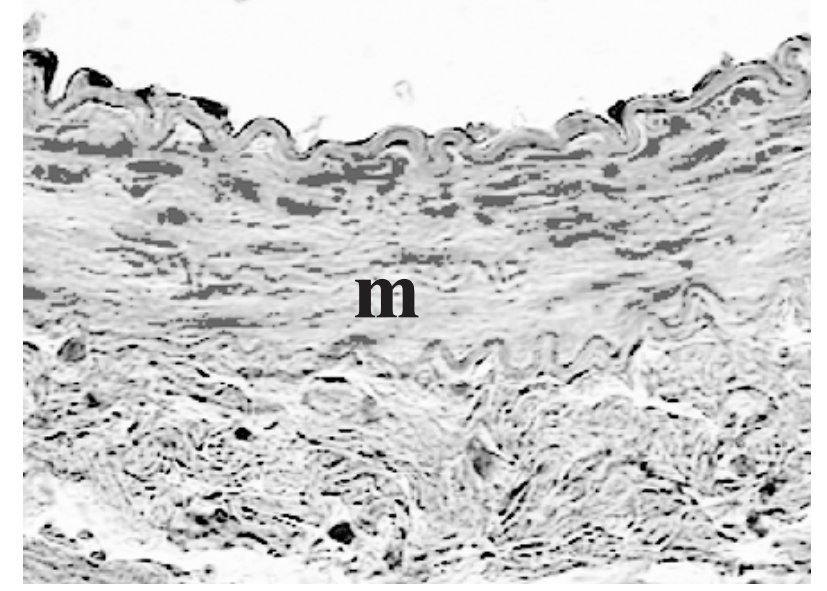

FIGURE 5 - Photomicrographs of irradiated group at 2 PO days showing the nuclei of smooth muscle cells (SMCs) in the medial layer (m) stainned in blue. A and C, before processing the captured images and B and D, after processing of the images.

(hematoxylin and eosin $-40 \mathrm{X}$ magnification).

Media layer focal necrosis was observed in the area included in the loop of the suture. Focal necrosis was higher in irradiated group than in control one although no significant. In control group at 2 PO the incidence was statistically significant higher than at 7 and $21 \mathrm{PO}$. In irradiated group focal necrosis was significant lesser at $21 \mathrm{PO}$. This is probably due to the strangulating effect of the sutures, which led to necrosis this was afterwards resolved and being replaced by tissue healing.

The histological evaluations showed the presence of tissue reaction (Langhans' or foreign body-type giant cells) to the nylon thread, reaction type strange foreign, in crescent order from 2, 7 to 21 days of observation. For the 21 days, the reaction was present in $100 \%$ of the animals of both groups, showing no influence of radiation on this type of inflammatory reaction.

\section{Discussion}

Experimental rat models have been used to study, develop and determine patency microsurgery technique, chronic and acute rejection in organ transplantation and small-vessel allografts, graft biological behavior and arterial trauma (crushing syndrome, limb autograft, thrombosis) $)^{5,6,20,21,22,23}$.

The operative approach to the femoral artery, a peripheral vessel with a relatively high percentage of muscle cells in its wall, avoid laparotomy and exposition of vital structures to direct radiation and systemic alterations (there is no radiosensitive organ in the extremities), lesser hydroelectrolitic disturbs besides this region often has been used in vascular surgery practice (angioplasty, bypass) ${ }^{24}$.

Therefore we chosen the rat femoral artery to study the effects of gamma-irradiation and to avoid 
alterations associated to radiation it was not used the same animal as control in contrast to report by Mayberg et al. ${ }^{15}$ Hirai et al. ${ }^{25}$

With the advent of modern microsurgical procedures and an improved understanding of the cellular dynamics of vascular graft adaptation, arterial grafts are being used more frequently in surgical practice.

The beneficial effects of irradiation may also be useful in smaller vessels since intimal hyperplasia following vessel wall injury may be independent of the native vessel diameter.

Currently, most animal and human clinical studies investigate the effects of different irradiation doses in prevention of stenosis utilizing either beta or gamma radiation from endoluminal (wire seeds, stents and balloons) or external sources have been realized ${ }^{26}$.

The role of external beam radiation in the treatment of intimal hyperplasia is not well established. There remains a debate among the researchers in the field about the effectiveness of external beam radiation.

External beam radiation (EBR) offers several potential advantages over an endoluminal source: - the delivered dose using EBR is uniform and it is not likely to be affected significantly by tissue heterogeneities of the vessel wall, such as eccentric lesions or calcifications ${ }^{27}$. The timing of radiation is flexible, provided it is given within the therapeutic window during which radiation might be effective ${ }^{28}$. Mayberg et al. ${ }^{15}$ demonstrated the importance of the timing of radiation in control of intimal hyperplasia in a rat carotid model (balloon inflation). They have found that radiation delivered 1 day after vessel injury was more effective than identical doses delivered at 3 or 5 days post injury.

For practical reasons, the use of an endoluminal source is restricted to the immediate endovascular periprocedural period; as discussed this may not be the optimum time to radiate the site of angioplasty. In comparison, EBR can be delivered at any time after an endovascular or open procedure. - for doses higher than 18-20 Gy, as may be required in human disease, dose fractionation is more practical using EBR. Dose fractionation has the advantage of less late radiation toxicity than a single dose regimen. The potential complication of prolonged vascular catheterization to deliver a large dose is also mitigated using an external source. - EBR eliminates the inherent exposure and personnel safety issues that exist with the use of endoluminal sources.

The use of EBR has two principal disadvantages: it is undesirable in certain anatomic location where other radiosensitive tissues may be exposed; and the difficulty in precise localization of the target volume in some vascular beds in motion such as the coronary arteries.

The effective dose for control of stenosis (restenosis) varies from species to species and hints as to the probable effective dose for humans may come from the ongoing clinical trials.

Although there are differences in the reported effective doses to prevent intimal hyperplasia, we choose the single dose of 15 Gy because it was the lowest reported effective dose in rats without side effects and significant wound healing alterations ${ }^{14,15}$, but some no significantly, alterations were observed $(6.5 \%)$.

After placement of the vascular grafts in both human patients and experimental animals it occurs endothelial denudation, proliferation of smooth muscle cells in media layer and migration to the intima promoting intimal hyperplasia, that is a result of the vessel wall's response to injury ${ }^{28}$.

Histological studies of rat autologous vein-to-artery grafts realized by Purcell et al. ${ }^{20}$ conducted from 1 week to 2 years, $1 \mathrm{~mm}$ in diameter and $4 \mathrm{~mm}$ long, determined that nearly all of the original graft issue is phagocytosed by 2 weeks after surgery and it is replaced by regenerated tissues derived from the adjacent host artery. They considered that this is a very rapid regenerative response, whereby a new "pseudo-artery" with endothelium and smooth muscle develops within 4 weeks of the placement of the graft

Machiarelli et al. ${ }^{29}$ studied on rat femoral artery the end-to-end anastomosis in intervals of time. They observed that during the first week wide disendotheliazed areas occurred and the endothelial cells present around the damaged areas were often partially detached or showed broken limits.

Therefore, we choose the anastomotic graft area to study it and observed the control group of neoformed endothelial cells above the internal elastic lamina for $90 \%$ of control group at $7 \mathrm{PO}$ and for all specimens at 21 PO. In the irradiated group, we observed reduction the degree of covering of the vascular wall for the neo-formed endothelium what might be associated to gamma radiation effects.

Purcell et al. ${ }^{30}$ studying arterial grafts in rats observed that intimal hyperplasia in the arterial segment develops rapidly over the fist 2 wk after graft placement and results in a total wall thickness that was significantly greater than the intima-plus-media of the host artery.

It could be showed in this study that for the control group at $21 \mathrm{PO}$ all specimens had been develop intimal hyperplasia with smooth muscle cell proliferation 
and for the irradiated one the intimal hyperplasia was suppressed (significantly reduced) compared with the irradiated group at 7 and $21 \mathrm{PO}$ and the presence percentage of smooth muscle cell were inhibited.

Further investigation of the long-term morphological alterations may be needed.

\section{Conclusion}

The external single dose of 15 Gy gamma-radiation delivered at first postoperative day of femoral artery reimplant of rats may reduced the endothelial cells regeneration and the percentage of lumen stenosis and prevent intimal hyperplasia in the 2, 7 and 21 postoperative days established.

\section{References}

1. Geary RL, Nikkari SP, Wagner WD, Williams K, Adams MR, Dean RH. Wound healing: a paradigm for lumen narrowing after arterial reconstruction. J Vasc Surg 1998;27:96-108.

2. Allaire E, Clowes AW. The intimal hyperplastic response. Ann Thorac Surg 1997; 64: 38-42.

3. Clowes MM, Lynch CM, Miller AD, Miller, DG, Osborne WRA, Clowes AW. Long-term biological response of injured rat carotid artery seeded with smooth muscle cells expressing retrovirally introduced human genes. J Clin Invest 1994;93:644-51.

4. Häyry P, Yilmaz S. Role of growth factors in graft vessel disease. Transplant Proc 1995;27(3):2066-7.

5. Hullet DA, Geraghty JG, Stoltenberg RL, Sollinger HW. The impact of acute rejection on the development of intimal hyperplasia associated with chronic rejection. Transplantation 1996,27:1842-6.

6. Moussavian M, Casterella PJ, Teirstein PS. Restenosis after angioplasty. Curr Treat Options Cardiovasc Med 2001;3(2):103-13.

7. Cain BS, Meldrum DR, Selzman CH, Cleveland Jr JC, Meng XM, Sheridan BC, Banerjee A, Harken AH. Surgical implications of vascular endothelial physiology. Surgery 1997; 122:516-26

8. Bauters C, Isner JM. The biology of restenosis. Prog Cardiovasc Dis 1997; 40:107-16.

9. Ishiwata S, Robinson K, Chronos N, Croker IR, King SB 3rd. Irradiation and postangioplasty restenosis: a recent overview. Jpn Heart J 2000;31: 541-70.

10. Bult H. Restenosis: a challenge for pharmacology. Trends Pharmacol Sci 2000; 21 (7):274-9.

11. Polterauer P, Nanobachvili J, Fuegls A, Huk I. Vascular surgery between the millenniums. Vasa 2000;29(1):17-27.

12. Waksman R, Croker IR. Radiation for prevention of restenosis where are we? Int J Radiat Oncol Biol Phys 1996;36:959-61.

13. Chougule PB. Vascular radiation therapy to reduce coronary artery restenosis. Surg Oncol Clin N Am 2000;9:577-84.
14. Shimotakahara S, Mayberg MR. Gamma irradiation inhibits intimal hyperplasia in rats after arterial injury. Stroke 1994:25:424-8.

15. Mayberg MR, Luo Z, London S, Gajdusek C, Rasey JS. Radiation inhibition of intimal hyperplasia after arterial injury. Radiat Res 1995; 142:212-20

16. Clowes AW, Reidy MA, Clowes MM. Mechanisms of stenosis after arterial injury. Lab Invest 1983.;49:208-15.

17. Clowes AW, Schwartz SM. Significance of quiescent smooth muscle migration in the injured rat carotid artery. Lab Invest $1985 ; 56: 139-45$

18. Wolfe TL. Guide for the care and use of laboratory animals Washington. National Academy Press;1996.

19. Chow SP, Huang CD, Chan CW. The histopathology of microvascular anastomosis a study of the incidence of vascular tissue changes. Microsurgery 1983:4:5-9.

20. Purcell C, Tennant M, McGeachie J. Neo-intimal hyperplasia in vascular grafts and its implications for autologous arterial grafting. Ann R Coll Surg Engl 1997; 79: 164-68.

21. Bayes-Genis A, Kantor B, Keelan PC, Altman JD, Lubbe DF,Kang JH, Schwartz RS. Reestenosis and hyperplasia: animal models. Curr Interv Cardiol Rep 2000; 2:303-8

22. Gasser M, Timmermann W, Thiede A. Segmental femoral artery allografts: histomorphological analysis of the rejection response in inbred rat strains.In: Timmermann W, Gassel H-J, Ulrichs K, Zhong R, Thiede A, editors. Organtransplantation in rats and mice. Berlin:Springer-Verlag; 1998. p. 359-64.

23. Darr UM, Tellides G. Techniques of skin, renal and vascular transplantation in the rat. In: Timmermann W, Gassel H-J, Ulrichs K, Zhong R, Thiede A, editors. Organtransplantation in rats and mice. Berlin: Springer-Verlag; 1998. p. 73-81.

24. Geise W. Guidelines for the use and care of small laboratory animals in transplantation research. In: Timmermann W, Gassel H-J, Ulrichs K, Zhong G R, Thiede A, editors Organtransplantation in rats and mice. Berlin: SpringerVerlog;1998. p. 27-40

25. Hirai T, Korogi Y, Harada M, Takahashi M. Prevention of intimal hyperplasia by irradiation. Acta Radiol 1996;37:229-33.

26. Fortunato JI, Glagov S, Bassiouny HS. Irrradiation for the treatment of intimal hyperplasia. Ann Vasc Surg 1998;12(5):495-503.

27. Popowski Y, Verin V, Papirov E, Nouet P, Rouzaud M, Grob E, Schwager M, Urban P, Rutishauser W, Kurtz JM. High dose rate brachytherapy for prevention of restenosis after percutaneous transluminal coronary angioplasty: preliminary dosimetric tests of a new source presentation. Int J Radiat Oncol Biol Phys 1995;33:211-5.

28. Razavi M, Rege S, Zeigler W, Mather K, Shen C, Smathers J, Gomes A, Withers R. Feasibility of external beam radiation for prevention of restenosis following balloon angioplasty. Int J Radiat Oncol Biol Phys 1999;44:363-7.

29. Machiarelli G, familiari G, Caggiati A, Magliocca FM, Riccardelli F, Miani A, Motta P.Arterial repair after microvascular anastomosis: scanning and transmission electron microscopy study. Acta Anat 1991;140:8-16.

30. Purcell C, Tennant M, McGeachie J. Vascular tissue adaptations in end-to-end autologous arterial grafts in rats: a morphometric analysis. J Anat 1998;192:37-43 
$\overline{\text { Costa RFB, Fagundes DJ, Juliano Y, Novo NF, Vieira WTT. Efeitos da radiação gama de fonte }}$ externa no reimplante da artéria de ratos: análise morfométrica. Acta Cir Bras [serial online] 2003 Mar-Abr;18(2). Disponível em URL: http://www.scielo.br/acb.

RESUMO - Objetivo: Estudar os efeitos da radiação gama de fonte externa no reimplante de artéria femoral. Métodos: Foram utilizados 62 ratos machos Wistar, distribuídos em dois grupos I (Controle) e II (Irradiado), constituídos de três subgrupos de observação: 2, 7 e 21 dias de pósoperatório (PO). As artérias femorais direitas foram retiradas e reimplantadas (anastomose términoterminal) por meio de técnica microcirúrgica. Os animais do grupo II, no primeiro dia de PO, foram irradiados na dose única de $15 \mathrm{~Gy}$, emitida de fonte externa. Realizou-se análise descritiva e qualitativa histológica nas lâminas coradas pelos métodos da hematoxilina e eosina (HE), Verhoeff e tricrômio de Masson. As alterações morfológicas da parede vascular foram quantificadas, a partir das imagens capturadas de um microscópio, usando-se um programa de computador, nos mesmos cortes histológicos corados pela HE. Analisou-se a camada íntima (neo-íntima e células endoteliais neoformadas) e a porcentagem de núcleos das células musculares lisas foi determinada na camada média e na hiperplasia intimal. Para análise estatística dos dados, aplicaram-se os testes exato de Fisher, qui-quadrado, Mann-Whitney, Kruskal-Wallis e análise de variância. Resultados: Observouse que, no grupo irradiado, a presença de células endoteliais neoformadas foi menor; a porcentagem de presença de núcleos de células musculares lisas na hiperplasia intimal foi menor comparado ao grupo controle, embora não significante; a estenose do lúmen vascular e a ocorrência de hiperplasia intimal foi significantemente menor e a porcetagem de células musculares lisas, na camada média, mostrou-se significantemente menor aos 7 e 21 dias de observação. Conclusão: A radiação de fonte externa emitida no primeiro $\mathrm{PO}$, na dose única de $15 \mathrm{~Gy}$, inibiu a regeneração de células endoteliais e a estenose do lúmen e a hiperplaisa intimal, aos 2, 7 e 21 PO no reimplante de artéria femoral de ratos.

DESCRITORES - Radiação ionizante. Efeitos de radiação. Reimplante. Artéria femoral. Ratos.

Conflict of interest: none

Financial source: none

Correspondence:

Regina de Faria Bittencourt da Costa

Praça Santa Terezinha, 54/91-B

03308-070 São Paulo - SP

Tel/Fax: (11)6941-8893

costara@uol.com.br

Data do recebimento: $15 / 12 / 2002$

Data da revisão: 02/01/2003

Data da aprovação: 21/01/2003 